\author{
Valentina Djakona \\ Vice-rector \\ ISMA University of Applied Sciences, Riga, Latvia \\ Stanislav Perminov \\ Postgraduate student \\ ISMA University of Applied Sciences, Riga, Latvia \\ ORCID: https://orcid.org/0000-0002-9353-8365 \\ E-mail:psb70@protonmail.com
}

\title{
Features of the formation of the global market for trust management services
}

\begin{abstract}
The article is devoted to the problems of the development of global markets for trust management services. The purpose of the article is to identify modern trends in the development of the global market for asset management services. The article uses the methods of quantitative empirical research, statistical analysis and visualization, comparative analysis and assessment of the dynamics of the main forms of development of trust management. The essence of trust management, its main forms, types of companies providing trust management services are disclosed. There is a gradual complication of the regulatory framework for trust management, although the features and models of regulation of trust activities or the activities of trust funds, the level of control and responsibility of the parties vary greatly in different countries. The advantages of trust management are systematized. The current trends in the development of trust management are characterized: regional asymmetry (mainly represented in the developed countries of Europe and the USA, the Asia-Pacific region is the fastest growing); the emergence of new forms (new instruments, institutional entities) and directions (the spread of offshore companies, the search for new markets). The formation of the global nature of the market is due to an increase in the volume of trust management services, an increase in income, the need to search for new forms of reliable savings and investments. The main development strategies of companies providing trust management services are identified and disclosed: global (focused on the global market), regional (focused on regional markets) and specialized (aimed at developing local markets or specialized products)
\end{abstract}

DOI: https://doi.org/10.30525/2500-946X/2021-1-8

\section{Statement of the problem}

The market for trust management services is in constant development and is implemented in many areas. Thus, the market for trust management services also includes the IPO market and other instruments for the placement of financial assets. In general, we can note that in modern conditions the formation of a global market for trust management services is just taking place, which is characterized by the presence of a large number of relatively small offices and firms serving only local funds or assets, very often representing only a part of companies or large legal or financial firms. ... At the beginning of the 21st century, the global market for trust management and corporate services (T\&CS) is emerging and is actively being professionalized.

\section{Latest scientific progress and publications review}

Trust management services are an integral part of modern banking and financial activities. The works of A. Asaul (Asaul, 2007), I. Smirnov (Smirnov, 2020), A. Vorotilov (Vorotilov, 2013), A. Kovalevich (Kovalevich, 2012), A. Mazajeva (Mazajeva, 2017), D. Fedulova (Fedulova, 2010) and others are devoted to the problems

\section{Keywords}

Trust, trust management, assets

JEL: F36, G11, G15, G21 of the essence and forms of implementation of trust management. General issues of asset management are widely discussed in the works of Woodhouse J. (Woodhouse J., 2003; 2018), Loistl O., Petrag R. (Loistl \& Petrag, 2003). Nevertheless, the extremely uneven distribution of this type of banking services among the countries of the world is a fact. Trust management of assets is widely represented in developed countries - the USA, Europe, etc. In developing countries, Eastern European countries, this service has even greater prospects for development. At the same time, significant diversification of banking instruments and technologies leads to the fact that trust management services are increasingly reaching the global level. The formation of a global market for trust management services is taking place, which requires appropriate research and analysis.

\section{The purpose and problem of research}

The purpose of the article is to identify modern trends in the development of the global market for asset management services.

\section{Methodology}

The article uses the methods of quantitative empirical research, statistical analysis and visualization, comparative analysis and assessment of the dynamics of the main forms of development of trust management. 


\section{Results of the research}

Trust management of assets involves the receipt of income as a result of the management of property by third parties. In the value chain in trust management, a certain system of relationships is formed between its participants (Figure 1).

At the first stage of creating additional value in trust management, the asset management process is included, the creation and management of a trust, the formation of funds, and the formation of listing services. The second stage is determined by the registration and maintenance of assets, bank accounts, preservation and verification of accounts and assets. In addition, at this stage, preparation of financial statements, accounting services, registration and payment of taxes, accounting, reporting (financial and investment), custody services, treasury services, listing, profitability planning, charity and philanthropy, cash management takes place. At the last stage, legal entities or business structures are liquidated and closed, as well as excluded from the listing.

Several types of companies (or trustees) can serve different segments of the trust services market:

- institutional clients - specialized companies working with alternative investment, illiquid funds, etc. This type of activity is riskier, requires increased margins and increased attention in work, but this type of activity is most attractive for managers;

- individual clients (private) - mainly work is carried out with individual trust funds, which are created for a long time, require individual work and long-term management plans;

- corporate clients are the most active part of the market, requiring a lot of attention and rather high volatility, which reduces its attractiveness. In addition, corporate accounts imply asset management in various jurisdictions, which, on the one hand, simplifies management, on the other hand, it greatly complicates, since it implies a short term of operation of such a trust (Trust..., 2019).

Working in countries with different jurisdictions is becoming more common in the context of the formation of the global market for T\&CS services, and although this, on the one hand, affects the conditions for conducting activity, on the other hand, it has many attractive features:

- simplicity of organizing and conducting business activities;

- the ability to choose a reliable legal framework and legal procedure, a politically stable economy;

- tax incentives or low taxation in general;

- a developed financial services market with a wide range of services.
The level of development of the trust management services market in any country is determined by the following factors: the degree of development of the processes of accumulating financial resources; the activity of savings processes and the investment component. An important component of relationships in the trust management market is the level of development of banks, financial infrastructure in general, and technologies in the financial sector. Thus, the development of the trust services market is based on the following key trends:

1. The level of general development of the country, economic stability and stability of financial markets.

2. Features and characteristics of the general development of the banking system in the country, the dominance of the banking or financial sectors, or markets.

3. Peculiarities of behavior models of investors or population in the country.

In the process of formation of the trust management services market, it becomes more complex due to the mixing of funds from different clients. If at the initial stage of market development these funds practically did not overlap, since their servicing took place in specialized companies, then with the growth of the size of the companies and servicing the accounts of clients of various levels, the consolidation of assets takes place. At the present stage of market development, we can distinguish segments: funds, private individual clients and corporate clients. At the same time, the forms of service acquire the features of not only trusts, but also custodian or fiduciary funds or other special purpose funds, which leads to the formation of cross flows of sale of services. Most of the services provided by companies providing trust management are permanent (we include administration, maintenance, reporting, etc.), however, at the present stage, services are also emerging for the formation of special legal entities or structures that deal with the accounts of only one client, while often mixing its assets with the assets of other clients, redistributing both risks and profits.

The formation of the industry occurs due to the merger of companies, their accounts, the creation of common mutual funds, funds focused on direct investment (which provides stable income and the ability to manage assets at a higher level). However, in the process of market formation, "childhood illnesses" arise that are characteristic of any activity at the stage of formation of regulatory support and tax settlement, since this type of activity can be successfully used for tax evasion. Due to the huge number of types of trust management services and types of companies that can provide this type of activity, questions of the complexity of regulation arise (The coming..., 2017).
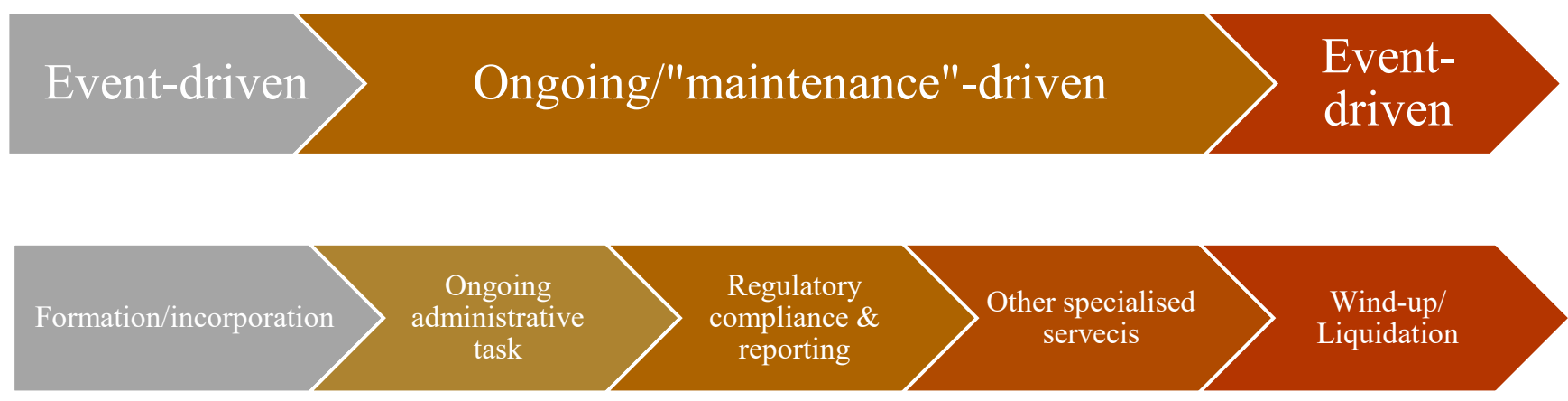

FIGURE 1 The value chain in trust (Trust..., 2019) 
At the same time, the development of regulatory documents and taxation creates barriers to entry into the market. Thus, the increase in the risks of functioning, in turn, contributes to the use of non-classical instruments for trust management, for example, direct investments, or the formation of a fixed rate for services (Trust..., 2019).

The features and models of regulation of trust activities or the activities of trust funds, the level of control and responsibility of the parties are recorded in government documents and vary greatly in different countries. In general, it should be noted that there is a gradual complication of the regulatory framework for trust management. On the one hand, the regulation of trust activities has been going on for a long time, but at the present stage new countries are joining this process, which complicates the regulatory framework and, accordingly, the forms of work in the trust management market. This complication of the financial services market landscape makes personal asset management more difficult, which contributes to the development of the trust services (T\&CS) market. In addition, the attractiveness of the markets is also determined by the long-term period of work with one financial representative, which guarantees (or increases) the stability of income, which in turn leads to an increase in the number of individual investors (or the attraction of private capital); companies are especially active in the market: Sanne Group, Intertrust, JTC (Trust..., 2019).

A special place in financial activity for trust services is occupied by offshore companies, which provide all the conditions for conducting trust management, which is especially important for individual accounts and for the long term. The formation of a global market for trust services involves the active use of offshore zones or offshore jurisdictions, which, on the one hand, reduce taxation, but, on the other hand, carry risks, both financial and reputational. The latter are associated with the leakage of information about tax havens, which can be used for fraud and tax evasion, and in order to avoid international sanctions. In addition, reliable jurisdictions are actively used that provide tax relief (Luxembourg, Cayman base, Channel Islands, Hong Kong, Singapore), or guarantee the creation of legal entities on rules of operation that are understandable to everyone.

According to the estimates of Bain \& Company, the growth opportunities of the world market are $3-5 \%$, which is primarily caused by the growth of general welfare, the formation of individual accounts, respectively; the increasing complexity of corporate taxation and regulation of their activities, as well as the need to manage funds (individuals and legal entities) in order to generate additional profit or preserve the initial capital. There is no doubt that economic growth contributes to the growth of the market for trust services and financial services (Figure 2).

Among the general trends in the development of the global market, we can note: the recovery of the world economy and an increase in the welfare of individuals, an increase in the number and quality of regulatory acts, leading to a complication of the market and an increase in the amount of capital when recalculated per investor. Growth of this segment is forecasted up to $4 \%$.

Fund administration (management) also includes hedge funds, which in general can reach $60-70 \%$ of all funds in general, and have been demonstrating a dynamic increase in assets recently, in general, up to $7 \%$ over the analyzed period. In general, more and more funds are channeled into management, which expands the range of services and attracts both individual companies and financial market entities.

At the same time, it can be noted that in some aspects the increase in regulation constrains the growth of the market and can lead to a decrease in the number of legal structures, however, to an increase in their value and revenue when recalculated per company. Growth in general is determined at the level of up to $5 \%$.

As noted above, this is a gradual complication of the market, blurring of the boundaries of various segments (hedge funds, custodian services, fiduciary, etc.), which in their essence and characteristics are forms of trust management. However, the market is consolidating through mergers and acquisitions, which forces companies and trustees to change management strategies and use marketing to attract new customers. The classic market is characterized by long-term development strategies and individual communication with the client to build a private capital management strategy. At the current stage of market development, sub-segments appear that do not accept such instruments. There is an expansion of development strategies in connection with entering new markets. Bain research shows that there are three key strategies that are popular: targeting a global platform; regional or special jurisdiction; and focus on the consumer segment or specialization in the service (Table 1 ).

Companies operating on a global scale operate in virtually all segments and in many jurisdictions, which is made possible through mergers and acquisitions. The complexity of this approach is the need for deep integration of newly acquired companies and the development of new markets. An example of the implementation of such a strategy can be the activity of the Intertrust company, which forms a complex offer of services based on the needs of the beneficiaries or a group of beneficiaries. The Dutch company has built its strategy through mergers and acquisitions, attracting new customers from new segments. Initially, it specialized in private capital, but now it serves real estate funds, and multinational corporations, banks, financial companies, providing an average annual growth rate of revenue of $22 \%$, EBITDA margin of over $37 \%$ (The coming..., 2017).

Companies implementing the strategies of regional leaders focus on a specific jurisdiction or geographic region and, accordingly, develop strategies within the selected market. This strategy is quite attractive for companies operating in reliable jurisdictions, for example, Tricor operates only in the Asian market (Hong Kong and Singapore). Under British jurisdiction, it concentrates on servicing branches or subsidiaries of multinational corporations, local or regional companies. Given the attractiveness and dynamism of the development of these Asian cities, the concentration of business activity, it is not surprising that Tricor is attractive for the formation of accounts under trust or asset management, which led to an average annual growth of revenue of 5\%, and the company's operating profit margin is about $30 \%$ (The coming..., 2017).

Another market coverage strategy involves the company's specialization in a narrow segment or in a narrow range of services. Such a business is built on a deep and long-term relationship with a client, study and knowledge of his needs and preferences, knowledge of specific products and asset management tools. This strategy is most often implemented for private equity, or real estate funds. An example of the successful implementation of such a strategy 


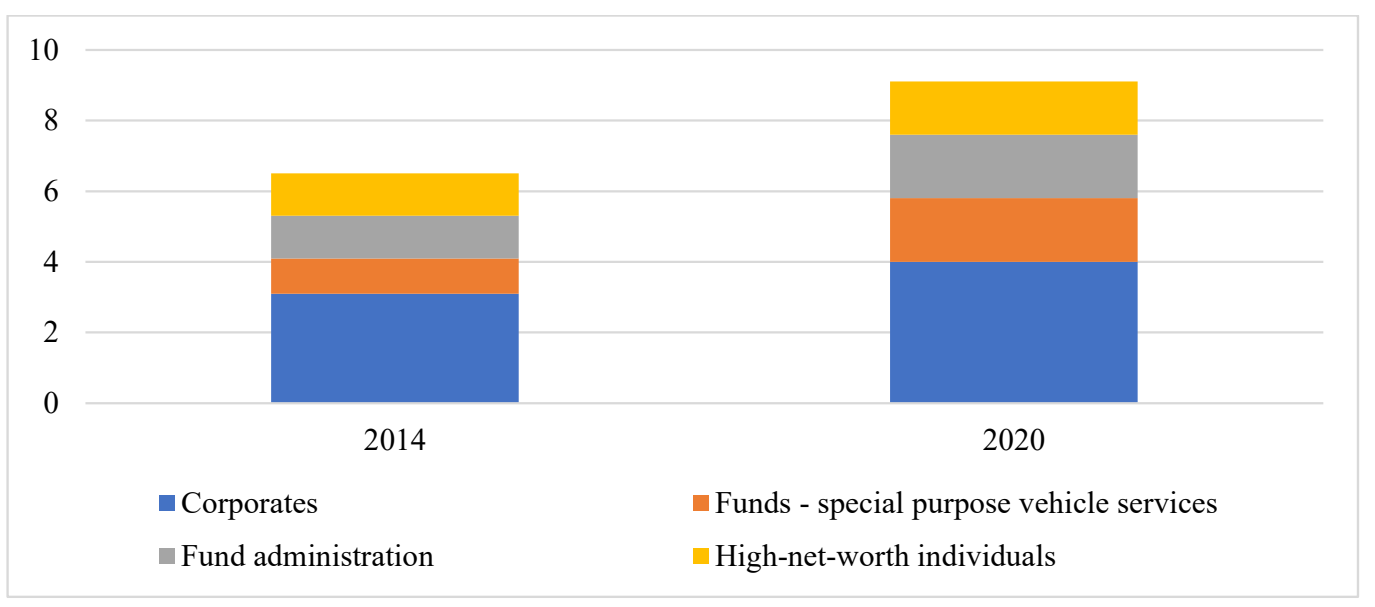

FIGURE 2. Global T\&CS market, value, billion euros (The coming..., 2017)

is the company Alter Domus, which specializes in private wealth management. Despite the narrow segment, such a strategy helped the company to cover both the European and Asian markets, mastering the American market as dynamic enough for an investor to profit from the accounts and assets. This led to an average increase in revenue of $13 \%$ (The coming..., 2017).

The choice of the company's strategic development depends on its capabilities and, accordingly, on the priorities of its activities. Global companies must first of all form and provide a single point of access to key services, understand the formation of value chains for multinational customers and resellers. In turn, regional leaders must first of all understand the peculiarities of the functioning of this market and the peculiarities of the use of intermediaries in a particular jurisdiction.

It should be noted that at the present stage of market development for global and regional companies, it is not enough to work only with existing customers. In this regard, marketing activities and representation in the global network are becoming more active, since this gives the opportunity to attract customers from all over the world, thus forming both a client and intermediary base. It should be borne in mind that for certain types of trust management activities, changing an agent can be quite complicated and can complicate taxation, especially if the structure of assets under management is rather complex (Figure 3).

Most companies use intermediaries or partners to improve service that can improve service to beneficiaries.
These intermediaries can be lawyers, bankers, specialized accountants who can serve new market segments or provide information on new jurisdictions. The segmentation of markets is a consequence of its globalization, expansion of jurisdictions, complication of the system of relations, the transition of trust management from pure trust relations to more complex forms in various market segments and clients.

For example, the Vistra company in its activities implements a strategy of wide market coverage, working both in the intellectual property market and the research segment of Thomson Reuters, using Baring Private Equity and Onex Partners, which, being part of the Vistra company structure, specialize in these markets. ... This feature is dictated by market requirements: on the one hand, regulatory requirements become more complex, and on the other, they need to be adapted to the needs of regional or local markets.

In general, in the process of consolidation of the T\&CS market, experts expect these tendencies to further strengthen and determine global leaders, that is, a small list of firms that will control a significant part of the market. The key issues for choosing a development strategy are issues related to market position, customers, internal processes and regulatory or administrative regulation.

The main aspects of building a strategy are identifying the most profitable segments, positioning, key differences between services and competitors, financial results and performance indicators, dynamics and quality of the

TABLE 1 Key development strategies of companies (The coming..., 2017)

\begin{tabular}{|c|c|c|}
\hline Strategy & Characteristics & $\begin{array}{l}\text { Examples of companies } \\
\text { operating in the segment }\end{array}$ \\
\hline Global platform & $\begin{array}{l}\text { - Global scale of operation } \\
\text { - Ability to serve multiple customer segments } \\
\text { - Service in all jurisdictions } \\
\text { - Acquisitions and excellent Integrations }\end{array}$ & $\begin{array}{l}\text { Intertrust } \\
\text { TMF Group } \\
\text { Citco } \\
\text { Vistra }\end{array}$ \\
\hline Regional or special jurisdiction & $\begin{array}{l}\text { - Local expertise and specialization in regulatory acts } \\
\text { - Full range of services for all segments within a specific jurisdiction or geographic } \\
\text { region }\end{array}$ & $\begin{array}{l}\text { Estera } \\
\text { Tricor } \\
\text { CT } \\
\text { CSC }\end{array}$ \\
\hline $\begin{array}{l}\text { Consumer segment or product } \\
\text { specialization }\end{array}$ & $\begin{array}{l}\text { - Understanding the needs of customers in a specific segment } \\
\text { - Long and deep relationships with clients } \\
\text { - High level of professionalism in a certain segment of services } \\
\text { - Expansion into related areas such as fund management, etc. }\end{array}$ & $\begin{array}{l}\text { Alter Domus } \\
\text { State Street } \\
\text { Aztec Group }\end{array}$ \\
\hline
\end{tabular}




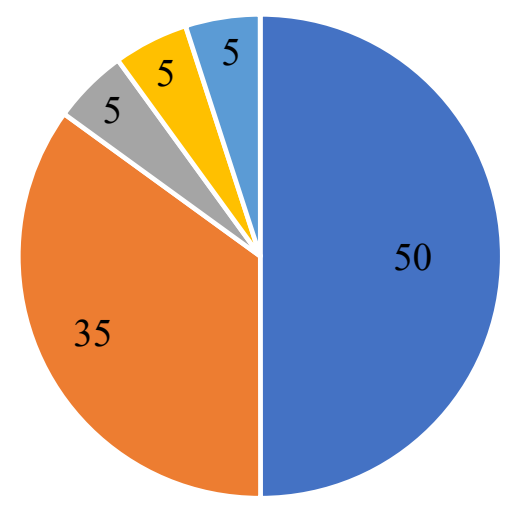

- Never, it is complex to change

- Very rarely, only if there is a major relationship or service issue

- Very rarely, only if they don't cover a specific jurisdiction

$\unrhd$ Rarely, only if key relationship person leaves the company

- Rarely, only if prices rise too much

FIGURE 3. Reasons for changing the trust service provider (The coming..., 2017)

company's growth and its financial performance. With regard to the customer base, the basic aspects are to determine the company's ability to attract new customers, identify their sources, understand the possibilities of building long-term relationships with both customers and intermediaries, the structure and quality of the customer base, the size of the customer portfolio. Internal reserves and processes require determining the company's capabilities to implement the strategy, analyzing the dynamics of staff turnover, analyzing the possibility of working in new jurisdictions or in a new regulatory environment, introducing new technologies in client asset management. In general, only a comprehensive solution to these issues can provide companies with holistic growth and the ability to determine their place in the new global market for trust management services. According to Bain experts, only a clear understanding of the market strategy can give the company the opportunity to compete and expand its leadership (through M\&A strategies or price differentiation) (The coming..., 2017).

\section{Conclusions}

Thus, the market for trust management services is an actively growing segment of banking and financial activities. It is constantly growing and looking for new tools and mechanisms for its development. The volume of the world market for trust management services is growing dynamically, which indicates the strengthening of its global nature. In general, the trust management services market is characterized by: dynamic growth, diversification of financial products and services, further market segmentation. Various strategies for the development of companies in the trust management services market are highlighted: global, regional or specialized positioning. The study of these issues is relevant for further scientific research.

\section{References}

[1] Asaul, A. N., Abajev, H. S., \& Molchanov, Ju. A. (2007). Upravlenije, ekspluatacia i razvitije imuschestvennih komleksov. SPb.: Gumanistica. E-source: http://www.aup.ru/books/m7/2_1_5.htm

[2] Fedulova, D. V. (2010). Grajdansko-pravovaja suschnost doveritelnogo upravlenija. Vestnik Tomskogo gosudarstvennogo universiteta, 1, 113-116. E-source: https://cyberleninka.ru/article/n/grazhdansko-pravovaya-suschnostdoveritelnogo-upravleniya/viewer

[3] Kovalevich, A. E. (2012). Doveritelnoje upravlenije: suschnost i soderjanije. Vestnik Belorusskogo gosudarstvennogo ekonomicheskogo universiteta, 4, 73-79.

[4] Loistl, O., \& Petrag, R. (2003). Asset Management Standards. DOI: 10.1057/9781403946058

[5] Mazajeva, A. V. (2017). Doveritelnoje upravlenije i trust: opit stran continentalnogo prava. Journal zarubejnogo zakonodatelstva i sravnitalnogo pravovedenija, 1. E-source: https://cyberleninka.ru/article/n/doveritelnoe-upravlenie-itrast-opyt-stran-kontinentalnogo-prava/viewer

[6] Smirnov, I. (2020). Doveritelnoje upravlenije. E-source: https://myfin.by/wiki/term/doveritelnoe-upravlenie

[7] The Coming Shakeout in Trust and Corporate Services (2017). E-source: https://www.bain.com/insights/the-comingshakeout-in-trust-and-corporate-services/

[8] Trust and Corporate Services: Global and Growing (2019). E-source: https://www.n1singer.com/blog/trust-andcorporate-services-global-and-growing/

[9] Vorotilov, A. (2013). Tonkost upravlenija. E-source: https://forbes.kz/finances/markets/tonkost_upravleniya/

[10] Woodhouse, J. (2003). Asset Management: concepts \& practice. E-source: https://www.researchgate.net/ publication/228905772_Asset_Management_concepts_practices

[11] Woodhouse, J. (2018). Value in Asset Management. Infrastructure Asset Management, 6(2), 1-25. DOI: 10.1680/ jinam.17.00040 